\title{
Edge effects and the impact of wildfires on populations of small non-volant mammals in the forest-savanna transition zone in Southern Amazonia
}

\author{
Ana Cristina Mendes-Oliveira ${ }^{1,4}$, Paulo Guilherme Pinheiro dos Santos ${ }^{1}$, Oswaldo de Carvalho-Júnior ${ }^{2}$, \\ Luciano Fogaça de Assis Montag ${ }^{1}$, Renata Cecília Soares de Lima ${ }^{1}$, \\ Suzanne Lúcia Silva de Maria ${ }^{1}$ \& Rogério Vieira Rossi ${ }^{3}$ \\ ${ }^{1}$ Laboratório de Ecologia e Zoologia de Vertebrados, Instituto de Ciências Biológicas, \\ Universidade Federal do Pará - UFPA, Rua Augusto Corrêa, 01, Guamá, CP 479, \\ CEP 66075-110, Belém, PA, Brasil \\ ${ }^{2}$ Ecologia Florestal, Instituto de Pesquisa Ambiental da Amazônia, R. Horizontina, Nova Canarana, \\ CEP 78640-000, Canarana, MT, Brasil \\ ${ }^{3}$ Departamento de Biologia e Zoologia, Instituto de Biociências, Universidade Federal de Mato Grosso - \\ UFMT, Av. Fernando Corrêa da Costa, 2367, Boa Esperança, CEP 78060-900, Cuiabá, MT, Brasil \\ ${ }^{4}$ Corresponding author: Ana Cristina Mendes-Oliveira, e-mail: cris.mastozoologia@ gmail.com
}

MENDES-OLIVEIRA, A.C., SANTOS, P.G.P., CARVALHO-JÚNIOR, O., MONTAG, L.F.A., LIMA, R.C.S., MARIA, S.L.S. \& ROSSI, R.V. Edge effects and the impact of wildfires on populations of small non-volant mammals in the forest-savanna transition zone in Southern Amazonia. Biota Neotrop. 12(3): http://www. biotaneotropica.org.br/v12n3/en/abstract?article+bn00912032012

Abstract: The impact of fire and edge effects on the community of small non-volant mammals was investigated in transitional Amazon forest within a matrix of soybean plantations. The animals were live trapped on 24 line transects, of which 16 were distributed in unburned areas and 8 in a burned area. A total of 11 species was recorded, including six rodents and five marsupials. The abundance and richness of small mammals appeared to decrease in burned areas, although this impact appeared to mask edge effects. In the absence of fire impacts, a positive relationship was found between mammal abundance and the distance from the forest edge. The impact of the edge effect on the diversity of small mammals appears to be influenced by the type of anthropogenic matrix and the ecological characteristics of the different species.

Keywords: Cricetidae, Didelphidae, diversity, soybean matrix, experimental fire.

MENDES-OLIVEIRA, A.C., SANTOS, P.G.P., CARVALHO-JÚNIOR, O., MONTAG, L.F.A., LIMA, R.C.S., MARIA, S.L.S. \& ROSSI, R.V. Efeito de borda e do fogo sobre pequenos mamíferos não-voadores (Rodentia e Didelphimorphia) em uma zona de transição Floresta-Cerrado ao sul da Amazônia. Biota Neotrop. 12(3): http://www.biotaneotropica.org.br/v12n3/pt/abstract?article+bn00912032012

Resumo: O efeito de borda e do fogo sobre a comunidade de pequenos mamíferos não-voadores foi investigada em uma área de transição entre Cerrado e Floresta em uma área de matriz de soja na Amazônia Oriental. Os indivíduos foram coletados em 24 transectos, dos quais 16 foram distribuídos em área sem efeito do fogo e oito distribuídos com efeito do fogo. Um total de 11 espécies foi registrado, incluindo seis roedores e cinco marsupiais. A espécie Hylaeamys megacephalus foi a mais abundante em áreas sem efeito do fogo. A abundância e riqueza de pequenos mamíferos não-voadores apresentaram uma diminuição em áreas queimadas, entretanto o efeito do fogo parece mascarar o efeito de borda nestas mesmas áreas. Em relação ao efeito de borda, sem nenhum efeito de fogo, a relação entre a abundância de pequenos mamíferos não-voadores com a distância da borda foi positiva. A relação entre a diversidade de pequenos mamíferos e efeito de borda pode ser ligada à vegetação matriz e características ecológicas de cada espécie.

Palavras-chave: Cricetidae, Didelphidae, diversidade, sojicultura, fogo experimental. 


\section{Introduction}

The expansion of beef ranching and industrialized soybean plantations in the northern extreme of the Brazilian state of Mato Grosso has been identified as the main threat to biodiversity on this Amazon frontier (Fearnside 2001, 2006, Barreto et al. 2006, Queiroz 2009). The area encompasses a transition zone between the Amazon rainforest and the central Brazilian savanna (Cerrado), a distinct forested system with a poorly-known biota (Ferreira-Junior et al. 2008, Araujo et al. 2009). This area suffered reduced impact in the past, but in the present day, the landscape has become highly fragmented, despite government legislation requiring the maintenance of forest reserves on private properties (Nepstad et al. 2006).

Forest fragmentation leads to increased tree mortality and reduced precipitation, making the remaining forests more vulnerable to fire (Mesquita et al. 1999, Laurance \& Williamson 2001, Monteiro et al. 2004, Balch et al. 2008). Edge effects constitute an additional negative ecological consequence of forest fragmentation, which involves physical and biological changes in the forest, resulting from the abrupt transition between the forest and the surrounding matrix (Kapos 1989, Williams-Linera 1990, Benitez-Malvido 1998, Laurance et al. 2002, Laurance 2008, Laurance \& Vasconcelos 2009).

Unfortunately, the impact of deforestation on the fauna of transitional Amazon forest has received little attention (Lacher \& Alho 2001, Silva \& Bates 2002). Despite their considerable diversity, this lack of data includes the small non-volant mammals, such as rodents and marsupials (Bonvicino et al. 2002, Mares \& Ernest 1995, Carmignotto 2004, Costa et al. 2005). In fact, this group of mammals has been poorly studied anywhere in the Amazon basin (Silva et al. 2001).

Few studies have focused on the impacts of edge effects on small non-volant mammals in tropical habitats (Laurance 1994, Goosem 2000, Asquith \& Mejía-Chang 2005, Fuentes-Montemayor et al. 2009). In Brazil, most of the available studies have involved the fauna of the Atlantic Forest or Cerrado. Stevens \& Husband (1998) recorded increasing diversity as a function of the distance from the edge in the Atlantic forest. In the same ecosystem, Pardini (2004) found significantly richer small mammal community in edge habitats in comparison with the interior of mature forest and concluded that arboreal species are more affected by edge effects. In all cases, edge effects have different consequences for different species (Figueiredo \& Fernandez 2004, Santos-Filho et al. 2008).

The effects of wildfires on the diversity of small mammals are as complex and poorly understood as edge effects. Studies in nontropical ecosystems, including deserts, grasslands, and temperate forests have recorded a decrease in the abundance of some species immediately after a wildfire (Quinn 1979, Fox 1982, Ojeda 1989, Fa and Sanchez-Cordero 1993, Churchfield 1997, Simon et al. 2002, Converse et al. 2006), reduced abundance in areas that are burned regularly (Sherburne-Junior 1959, Rana 1985) or the dominance of a few species in burned areas (Krefting \& Ahlgren 1974, Kern 1981, Clark \& Kaufman 1990). In most cases, the time elapsed since the disturbance seems to be an important variable determining the composition of the mammalian community (Vieira \& Marinho-Filho 1998, Ford et al. 1999, Simon et al. 2002, Torre \& Diáz 2004, Fisher \& Wilkinson 2005). In the Cerrado, Briani et al. (2004) and Vieira (1999) found that small mammals were relatively tolerant to such impacts, and were especially abundant during the early successional stages.

The present study evaluates the potential impacts of edge effects and wildfires on the species richness and abundance of small rodents and marsupials in the transitional forest of the southern Amazon basin. Specifically, the study area is located within a typical fragmented landscape within a matrix of soybean plantations.

\section{Methods}

\section{Study area}

The study was conducted in an area of transitional Amazon forest (Instituto... 2004), located on Tanguro Farm (13 $3^{\circ} 04^{\prime} 35.39^{\prime \prime} \mathrm{S}$ and $52^{\circ} 23^{\prime} 08.85$ ” W), $75 \mathrm{~km}$ north of Canarana, in the Brazilian state of Mato Grosso (Figure 1a). This farm encompasses 82,000 ha, of which 38,000 were used for soybean cultivation. The remaining area is covered by transitional Amazon forest affected by different levels of disturbance (Figure 1b). The climate is humid tropical, with mean annual precipitation of $1739 \mathrm{~mm}$ and a marked dry season from May to September (Balch et al. 2008).

This transition zone is a complex mosaic of Amazonian forest and Cerrado vegetation, with a lower plant species richness, lower canopy height, and lower leaf area index in comparison with the proper Amazon forest (Ackerly et al. 1989, Ivanauskas et al. 2004, Balch et al. 2008). These forests currently suffer some of the highest deforestation rates in Brazil due to the ongoing expansion of cattle ranching and soybean plantations (Instituto... 2006, Soares-Filho et al. 2006).

\section{Data collection}

Data collection was conducted between August 2005 and August 2007, during five field expeditions of twenty days each, three in the dry season and two in the rainy season. Samples were collected simultaneously in two forest plots with similar vegetation characteristics, defined as Plots 1 and 2 (Figure 1b). Just on the last expedition it was not possible to access the Plot 1 , on the last few days. Both plots contained 150 ha of continuous forest, and were bordered on one side by an abrupt transition between forest and soybean plantations. The distance between Plot 1 and 2 was about ten kilometers. Plot 1 was divided into three contiguous subplots of 50 ha (Figure 1c), including an unburned area as control (treatment UbA), a subplot in which experimental fires (inside the forest) were set in 2004 and 2007 (treatment F3), and a subplot in which experimental fires (inside the forest) were set annually (treatment F1). In these plots, data were collected shortly before the experimental fires were set. Plot 2, which was the same size as Plot 1, was unaltered throughout the study period, although it did present the same edge configuration of Plot 1 .

Mammals were live trapped with small $(23 \mathrm{~cm} \times 6 \mathrm{~cm} \times 5 \mathrm{~cm})$, medium $(23 \mathrm{~cm} \times 9 \mathrm{~cm} \times 8 \mathrm{~cm})$ and large $(38 \mathrm{~cm} \times 12 \mathrm{~cm} \times 10 \mathrm{~cm})$ Sherman traps and Tomahawk traps $(51 \mathrm{~cm} \times 19 \mathrm{~cm} \times 19 \mathrm{~cm})$. In both plots, the traps were distributed along 12 parallel transects $250 \mathrm{~m}$ apart (Figure 1c). Sixteen traps were set along each transect, 11 medium Sherman live-traps at a distance of $25 \mathrm{~m}$ from each other, together with 2 Sherman (large or small) and 3 Tomahawk traps chosen at random. A total of 192 traps were used in each plot, all of which were always set on the ground, where the effects of the experimental fire were more visible. Balch et al. (2008) noted that the forest at Tanguro Farm burned most intensely at ground level, probably because the layer of dry debris acts as fuel, while the more humid vegetation above dampens the flames (Barlow \& Peres 2003). The traps were baited with fruits, bacon and mixture of peanut with oil fish, and inspected every morning during sampling days.

For the investigation of edge effects was considered the distance from transect to the edge of the forest (adjacent to the soybean plantation). In both Plots, these distances varied from $30 \mathrm{~m}$ to $750 \mathrm{~m}$, with four treatments - the first row of transects at $30 \mathrm{~m}$ from the edge, the second $250 \mathrm{~m}$, the third $500 \mathrm{~m}$, and the fourth, $750 \mathrm{~m}$ (Figure 1c). Twelve transects were sampled in each Plot. The parallel distance between transects was $250 \mathrm{~m}$ and the distance between transects of 

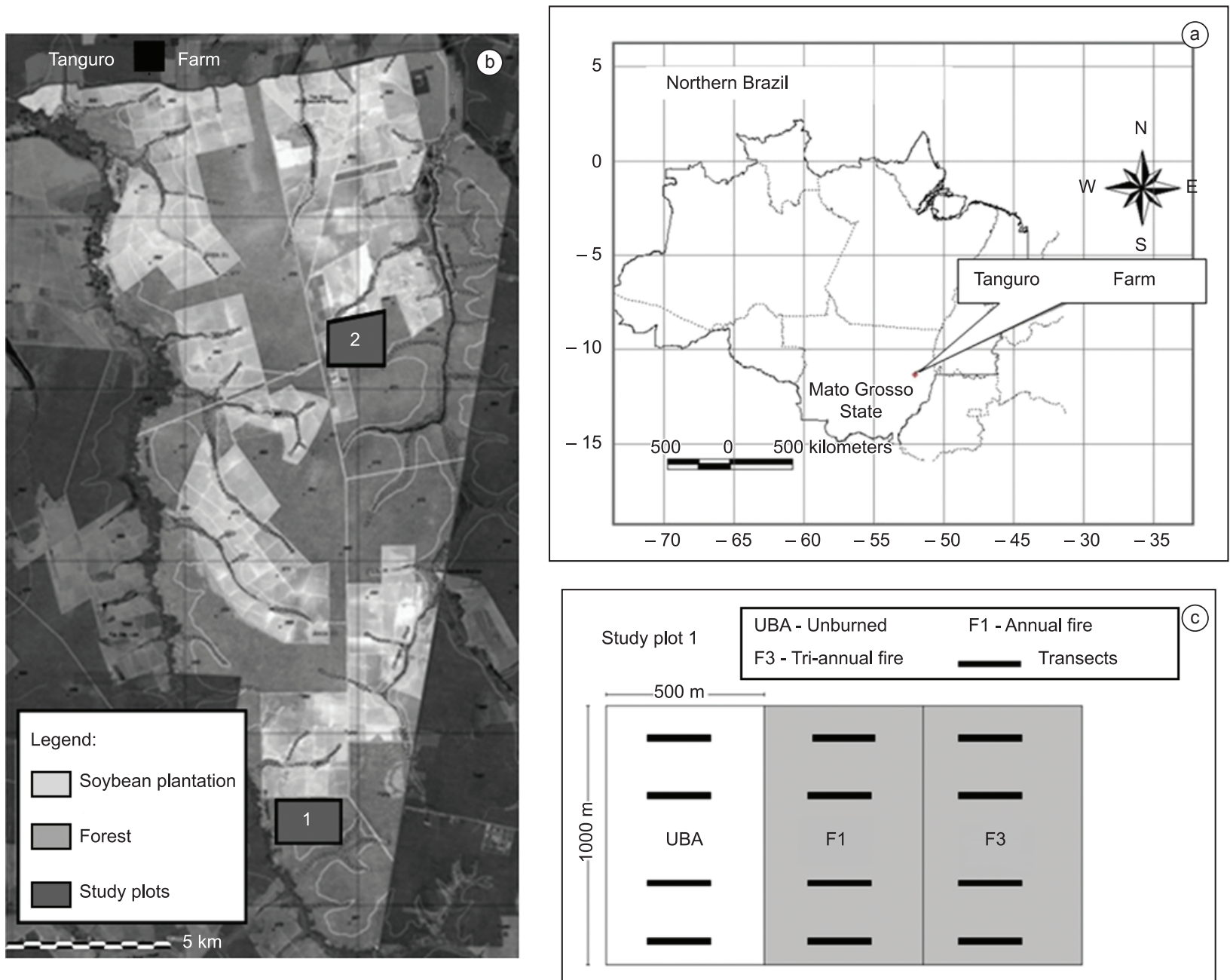

Figure 1. Location of the study area. a) Location of Tanguro Farm in southern Amazonia; b) Tanguro Farm; c) Details of sample plot 1.

Figura 1. Localização da área de estudo. a) Localização da Fazenda Tanguro na Amazônia Oriental; b) Fazenda Tanguro; c) Detalhes da parcela amostral 1 (queimada).

each subplot was 500 meters. For statistical analysis, each transect was considered to be an independent sample, given that, with the exception of Didelphis marsupialis Linnaeus, 1758, animals were only recaptured within the same transect, and not between them. The independence distance of samples at this study can be corroborated by the literature about habitat use by small mammals (Nupp \& Swihart 2000, Jorgensen 2004, Dalmagro \& Vieira 2005)

\section{Data analysis}

The data were checked for normality and homogeneity of variance, which permitted the use of a parametric two-factor ANOVA, which was applied to verify the effects of the distance from the edge and of fire, and the interaction between these factors. The significance level was $5 \%$. A linear regression was used to verify edge effects in the unburned transects, including all transects in Plot 2 and those in subplot UbA of Plot 1. The approach was repeated omitting subplot $\mathrm{UbA}$, in order to assess the possible indirect effects of fire. A temporal analysis comparing the effects of fire between treatments (F1 and F3) were impeded by the inadequate number of transects in each subplot for replication.

For the comparative analysis of transects between plots, considering edge and fire effects together, a MDS ordination were applied, using the Bray-Curtis coefficient of similarity with the abundance transformed to $(\ln (\mathrm{N}+1))$. The adequacy of the MDS analyses was assessed by stress values, with values below 0.5 being considered reliable (Clarke \& Warwick 2001).

The autocorrelation was treated with spatial filters. To test if the distance between transects could be affecting the results of the tested effects on abundance and richness of non-volant small mammals, was applied a Mantel test using a spatial matrix of filters and geographical coordinators. The incidence was treated with Jaccard similarity and the spatial matrix by Euclidean distance.

\section{Results}

Total sampling effort in plot 1 was 9,792 trap nights, resulting in the capture of 26 individuals belonging to six species, including two rodents: Hylaeamys megacephalus (Fischer, 1814) $(\mathrm{n}=12)$ and Rhipidomys nitela Thomas, $1901(\mathrm{n}=7)$, and four marsupials: Didelphis marsupialis Linnaeus, $1758(\mathrm{n}=2)$, Micoureus demerarae (Thomas, 1905) $(\mathrm{n}=3)$, Marmosops bishopi (Pine, 1981) $(\mathrm{n}=1)$, and Marmosa murina (Linnaeus, 1758) $(\mathrm{n}=1)$. In plot 2, with a total of 10,752 trap nights, 367 individuals of 10 species were captured, including six rodents: $H$. megacephalus $(\mathrm{n}=302), R$. nitela $(\mathrm{n}=16)$, Necromys lasiurus (Lund, 1841) $(\mathrm{n}=11)$, Oligoryzomys cf. microtis 
(Allen, 1916) $(\mathrm{n}=7)$, Akodon sp. $(\mathrm{n}=2)$, and Calomys cf. tocantinsi Bonvicino, Lima \& Almeida, $2003(\mathrm{n}=2)$, and four marsupials: D. marsupialis $(\mathrm{n}=16), M$. demerarae $(\mathrm{n}=4)$, Metachirus nudicaudatus (É. Geoffroy, 1803) $(\mathrm{n}=5)$, and M. bishopi $(\mathrm{n}=2)$.

Considering only the edge effect, no difference was found between transects in either in species richness $(F=0.895 ; \mathrm{p}=0.461)$ or abundance $(F=1.852 ; p=0.171)$. However, the effect of fire decrease the abundance $(\mathrm{F}=11.435 ; \mathrm{p}<0.01)$ and richness $(\mathrm{F}=9.701 ; \mathrm{p}$ $<0.01)$ of small mammals on the burning sample Plots. Considering the two effects together, the statistical analyses presented an interaction between then, for both abundance $(F=16.808 ; \mathrm{p}<0.01)$ and richness $(\mathrm{F}=59.364 ; \mathrm{p}<0.01)$.

The linear regression analysis found no significant tendency in abundance with increasing distance from the edge $\left(\mathrm{r}^{2}=0.24\right.$; $\mathrm{p}=0,142)$ when all unburned transects were analyzed together (Figure 2a). However, when Plot 1 was excluded from the analysis, i.e. with no indirect fire effect, abundance increased significantly with distance from the edge $-\mathrm{r}^{2}=0.77 ; \mathrm{F}=33.84$; D.F. $=10 ; \mathrm{p}<0.01$ (Figure $2 b$ ). The reduced abundance of mammals in subplot UbA appears to be an indirect consequence of the successive fires in the adjacent Plots (F1 and F3). The results of this analysis may also have been influenced by the significantly greater abundance of H. megacephalus in Plot 2.

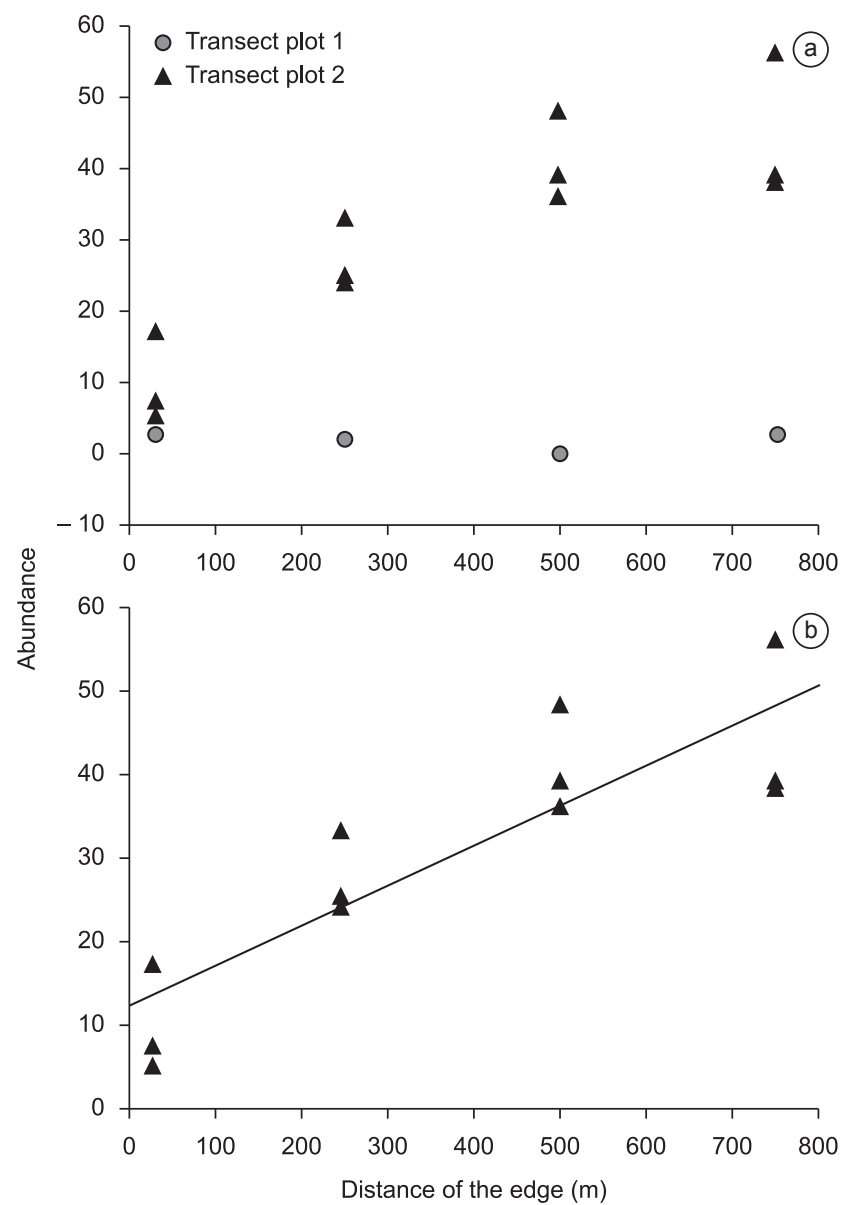

Figure 2. Relationship between the abundance of small mammals and the distance from the edge in the unburned transects $(n=16)$ of plots 1 and 2 (a), and in plot $2, \mathrm{n}=12$ (b).

Figura 2. Relação entre abundância de pequenos mamíferos não-voadores e a distância da borda em transectos não queimados nas parcelas 1 e $2(\mathrm{~N}=16)$ (a), e apenas em transectos não queimados na parcel $2(\mathrm{~N}=12)(\mathrm{b})$.
The MDS analysis identified two main groups (Figure 3), supported by the stress value of 0.01 . The ANOSIM analysis of the groups, including both edge and fire effects, confirmed significant differences between groups $(p=0.013)$. Two of three transects in Plot 2 located closest to the edge did not fit in with the general pattern for this Plot, possibly because the abundance of mammals was considerably lower, even in the case of $H$. megacephalus.

The Mantel test showed that there was no autocorrelation between samples using the spatial filters (Mantel 0.779; $\mathrm{p}=0.00009$ ).

\section{Discussion}

The results of the present study indicate that experimental fires had a highly negative effect on the abundance and richness of communities of small non-volant mammals (Krefting \& Ahlgren 1974, Fox 1982, Vieira 1999, Briani et al. 2004, Figueiredo \& Fernandez 2004). The relative abundance of $H$. megacephalus in plot 2 may have influenced the results, especially for the analysis of species abundance. This species is found mainly in upland forests in the Brazilian Amazon basin, but is also associated with the open forest formations of the Cerrado and Atlantic Forest (Fonseca et al. 1996, Oliveira \& Bonvicino 2006). Carmignotto (2004) reported that $H$. megacephalus prefers forested environments and is only occasionally found in open areas.

The absence of the terrestrial species Necromys lasiurus (Lund, 1840) and Oligoryzomys cf. microtis (Allen, 1916) from the burned areas may be related to the typical combustion pattern of wildfires in humid Amazonian forests, which are typically restricted to the forest floor (Barlow \& Peres 2003, Balch et al. 2008). It seems likely that these ground-dwelling species (Vieira et al. 2005, Oliveira \& Bonvicino 2006) are extremely vulnerable to the effects of fire over the short term. Similar considerations may be relevant to D. marsupialis and M. nudicaudatus, in particular the latter, which is exclusively terrestrial, and burrows beneath the leaf litter (Passamani 1995, Vieira \& Monteiro-Filho 2003, Rossi et al. 2006).

As the study only covered a two-year period, it was not possible to assess the long-term effects of experimental fire reliably. A series of different microhabitats may be created following successive wildfires, depending on the time passed since the previous fire, probably through the selection of different mammal species (Fox 1982, Briani et al. 2004, Vieira 1999). In any case, the small mammal assemblage may differ considerably between successional stages (Krefting \& Ahlgren 1974, Torre \& Diáz 2004, Fisher \& Wilkinson 2005).

Almeida et al. (2007) described an increase in the predation of seeds in burned areas at Tanguro Farm, especially those of smaller size such as Ormosia paraensis Ducke (Fabaceae), Trattinickia burseraefolia Mart (Burseraceae) and Maprounea guinanensis Aubl (Euphorbiaceae). These authors concluded that, over the medium term, fire would favor plants with smaller seeds, facilitating their predation by smallbodied species such as mammals. Barlow \& Peres (2003) observed a reduction in medium- and large-bodied vertebrates in burned areas, which would lead to a reduction in competition for food, favoring an increase in frugivorous-insectivorous species such as small mammals (Talamoni et al. 2008).

In the present study, the edge effect appeared to reduce species abundance, at least in the absence of fire. A similar pattern was observed by Santos-Filho et al. (2008), who recorded the highest richness and abundance in transects within forest fragments $(300 \mathrm{~m}$ from the edge) compared to those located closer to the pasture $(50 \mathrm{~m}$ from the edge) and at the edge of the forest. However, Pardini (2004) recorded a significantly higher species richness of small mammals at the edge of forest fragments in Atlantic Forest, while Malcolm (1997) 


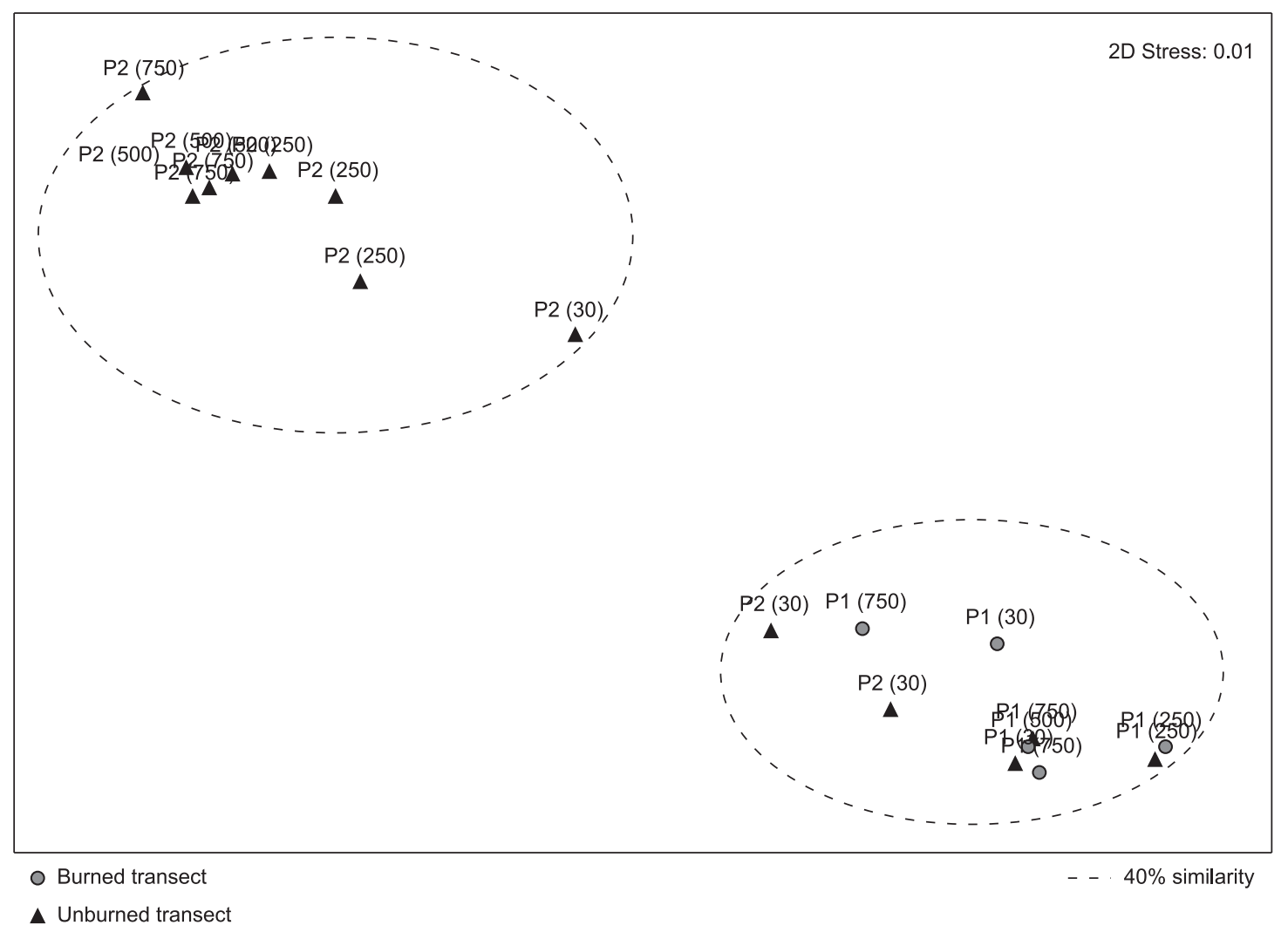

Figure 3. MDS analyses of the abundance of small mammals on all transects of plots 1 (P1) and 2 (P2) based on the Bray-Curtis coefficient of similarity. The numbers between parentheses indicate the distance from the edge.

Figura 3. Análise de ordenação MDS de pequenos mamíferos não voadores em todos os transectos de ambas as parcelas 1 (P1) e 2 (P2) (com coeficiente de similaridade de Bray-Curtis). Os números entre parênteses indicam a distância a partir da borda.

observed an increase in the abundance of small mammals in smaller forest fragments (1-10 ha) in central Amazonia.

The influence of the edge effect on the diversity of small mammals may be linked to the type of vegetation in the matrix and the ecological characteristics of the mammalian species. In a study of Amazonian forest fragments, Gascon et al. (1999) recorded a higher species richness and abundance of fauna in fragments set in a matrix of secondary forest in comparison with those surrounded by pasture. In the present study, most of the anthropogenic matrix was composed of soybean plantations in areas that had previously been pasture. The native vegetation of these areas was totally suppressed, and while the soybean plantation provides some cover, this was only short-lived due to annual harvesting.

However, the characteristics of the matrix may have had a positive effect on some species. For example, grass mice (Akodon sp.) were only recorded at the edge of the sample plots. This genus seems to have a preference for open areas, and Pardini (2004) recorded a greater abundance of Akodon cursor Winge, 1887 on the edges of fragments of Atlantic Forest, while the species was rare within the fragments. By contrast, $M$. nudicaudatus was only captured in transects at least $250 \mathrm{~m}$ from the edge, which suggests they prefer forest habitats. Santos-Filho et al. (2008) classified this species as "intermediate" in terms of habitat use, while the classified $H$. megacephalus as a "generalist", present throughout the forest, as observed in the present study. However, $R$. nitela, which was classified as an "intermediate" species by Santos-Filho et al. (2008) was also captured at all distances from the edge in the present study, even though this is an arboreal species, which was likely under- sampled in this study. The reduced number of specimens captured for some species, in particular scansorial and/or arboreal forms such as Micoureus demerarae (Thomas, 1905) and Oligoryzomys cf. microtis (Oliveira \& Bonvicino 2006), hampered the definition of ecological patterns in the present study.

Overall, the results of this study indicate that fire may be masking edge effects in plot 1 , given the lower abundance of mammals on all transects, even those furthest from the edge. This conclusion is supported by other studies, which have shown that edge effects may be intensified by recurrent disturbances such as wildfires (Laurance et al. 2002).

\section{Acknowledgements}

We are grateful to $\mathrm{CNPq} / \mathrm{PPG} 7 / \mathrm{MCT}$ and the Moore Foundation for financial support and the Maggi Group for permission to conduct research on Tanguro Farm. We also thank Daniel Nepstad, Jenniffer Balch, Claudia Stickler, Gina Cardinot and Paulo Brando for their scientific contributions, Oswaldo Portela and Arlindo Junior for their assistance in the field and Dr. Stephen Ferrari for his help in correcting text, particularly the english.

\section{References}

ACKERLY, D.D., THOMAS W.W., FERREIRA, C.A.C. \& PIRANI J.R. 1989. The Forest-Cerrado transition zone in southern Amazonia: Results of the 1985 Projeto Flora Amazônica Expedition to Mato Grosso. Brittonia 4(12):113-128. http://dx.doi.org/10.2307/2807515 
ALMEIDA, M.C., JUEN, L., CARDOSO, M.W., AZEVEDO, R.C., BARBOSA, D.C.F. \& MELO, F. 2007. Predação de sementes e intensidade do distúrbio do fogo em florestas de transição, Fazenda Tanguro, Querência, MT. Universidade Federal de Goiás, Programa de pós-graduação em Ecologia e Evolução, Goiás, p.31-36. Relatório não publicado.

ARAUJO, R.A., COSTA, R.B., FELFILI, J.M., GONÇALVEZ, I.K., SOUSA, R.A.T.M. \& DORVAL, A. 2009. Floristics and structure of a forest fragment at a transitional zone at the Amazon in Mato Grosso State, Municipality of Sinop. Acta Amazon. 39:865-877. http://dx.doi. org/10.1590/S0044-59672009000400015

ASQUITH, N.M. \& MEJÍA-CHANG, M. 2005. Mammals, Edge Effects, and the loss of tropical forest diversity. Ecology. 86(2):379-390. http:// dx.doi.org/10.1890/03-0575

BALCH, J.K., NEPSTAD, D.C., BRANDO, P.M., CURRAN, L.M., PORTELA, O., CARVALHO-JUNIOR, O. \& LEFEBVRE, P. 2008. Negative fire feedback in a transitional forest of southeastern Amazônia. Global Change Biol. 14:1-12.

BARLOW, J. \& PERES, C. 2003. Fogo rasteiro, nova ameaça na Amazônia. Ciênc. Hoje 34:24-29

BARRETO, P., SOUZA-JUNIOR, C., NOGUERÓN, R., ANDERSON, A. \& SALOMÃO, R. 2006. Human pressure on the Brazilian Amazon Forest Biome. World Resource Institute Report, 86p.

BENITEZ-MALVIDO, J. 1998. Impact of forest fragmentation on seedling abundance in a tropical rain forest. Conserv. Biol. 12(2):380-389. http:// dx.doi.org/10.1046/j.1523-1739.1998.96295.x

BONVICINO, C.R., LINDBERG, S.M. \& MAROJA, L.S. 2002. Small non-flying mammals from conserved and altered areas of Atlantic Forest and Cerrado: comments on their potential use for monitoring environment. Braz. J. Biol. 62(4B):765-774. http://dx.doi.org/10.1590/ S1519-69842002000500005

BRIANI, D.C., PALMA, A.R.T., VIEIRA, E.M.V. \& HENRIQUES, R.P.B. 2004. Post-fire succession of small mammals in the Cerrado of central Brazil. Biodivers. Conserv. 13:1023-1037. http://dx.doi. org/10.1023/B:BIOC.0000014467.27138.0b

CARMIGNOTTO, A.P. 2004. Pequenos mamíferos terrestres do bioma Cerrado: padrões faunísticos locais e regionais. Dissertação de mestrado, University of São Paulo, $404 \mathrm{p}$.

CHURCHFIELD, S. 1997. Community structure and habitat use of small mammals in grasslands of different successional age. J. Zool. 242:519-530. http://dx.doi.org/10.1111/j.1469-7998.1997.tb03853.x

CLARK, B.K. \& KAUFMAN, D.W. 1990. Short-term responses of small mammals to experimental fire in tallgrass prairie. Can. J. Zool. 68(11):2450-2454. http://dx.doi.org/10.1139/z90-340

CLARKE, K.R. \& WARWICK, R.M. 2001. Change in marine communities: an approach to statistical analysis and interpretation. 2nd ed. PRIMER-E, Plymouth, 172p.

CONVERSE, S.J., WHITE, G.C., FARRIS, K.L. \& ZACK, S. 2006. Small Mammals and Forest Fuel Reduction: National-Scale Responses to Fire and Fire Surrogates. Ecol. Appl. 16(5):1717-1729. http://dx.doi. org/10.1890/1051-0761(2006)016[1717:SMAFFR]2.0.CO;2

COSTA, L.P., LEITE, Y.L.R., MENDES, S.L. \& DITCHFIELD, A.D. 2005. Mammal conservation in Brazil. Conserv. Biol. 19(3):672-679. http:// dx.doi.org/10.1111/j.1523-1739.2005.00666.x

DALMAGRO, A.D. \& VIEIRA, E.M. 2005. Patterns of habitat utilization of small rodents in an area of Araucaria forest in Southern Brazil. Austral Ecol. 30:353-362. http://dx.doi.org/10.1111/j.1442-9993.2005.01447.x

FA, J.E. \& SANCHEZ-CORDERO, V. 1993. Small mammals population responses to fire in a Mexican high-altitude grassland. J. Zool. 230:343-347.

FEARNSIDE, P.M. 2001. Soybean cultivation as a threat to the environment in Brazil. Environ. Conserv. 28(1):23-38. http://dx.doi.org/10.1017/ S0376892901000030

FEARNSIDE, P.M. 2006. Desmatamento na Amazônia: dinâmica, impactos e controle. Acta Amazon. 36(3):395-400. http://dx.doi.org/10.1590/ S0044-59672006000300018
FERREIRA-JUNIOR, E.V., SOARES, T.S., COSTA, M.F.F. \& SILVA, V.S.M. 2008. Floristic composition, diversity and similarity of a submontane semideciduous tropical forest in Marcelândia - MT. Acta Amazon. 38:673-680.

FIGUEIREDO, M.S.L. \& FERNANDEZ, F.A.S. 2004. Contrasting effects of fire on populations of two small rodent species in fragments of Atlantic Forest in Brazil. J. Trop. Ecol. 20:225-228. http://dx.doi.org/10.1017/ S0266467403001093

FISHER, J.T. \& WILKINSON, L. 2005. Response of mammals to forest fire and timber harvest. Mammal Rev. 35(1):51-81. http://dx.doi.org/10.1111/ j.1365-2907.2005.00053.x

FONSECA, G.A.B., HERRMANN, G., LEITE, Y.L.R., MITTERMEIER, R.A., RYLANDS A.B. \& PATTON, J.L. 1996. Lista anotada dos mamíferos do Brasil. Occasional Pap. Conserv. Biol. 4:1-37.

FORD, W.M., MENZELB, M.A., MCGILLC, D.W., LAERM, J. \& MCCAYE, T.S. 1999. Effects of a community restoration fire on small mammals and herpetofauna in the southern Appalachians. Forest. Ecol. Manag. 11(4):233-243. http://dx.doi.org/10.1016/S0378-1127(98)003545

FOX, B.J. 1982. Fire and mammalian secondary succession in an Australian coastal heath. Ecology. 63(5):1332-1341. http://dx.doi. org/10.2307/1938861

FUENTES-MONTEMAYOR, E., CUARÓN, A.D., VÁZQUEZDOMÍNGUEZ, E., BENÍTEZ-MALVIDO, J., VALENZUELAGALVÁN, D. \& ANDRESEN, E. 2009. Living on the edge: roads and edge effects on small mammal populations. J. Anim. Ecol. 78(4):857-65 PMid:19426252. http://dx.doi.org/10.1111/j.1365-2656.2009.01551.x

GASCON, C., LOVEJOY, T.E., BIERREGAARD-JUNIOR, R.O., MALCOLM, J.R., STOUFFER, P.C., VASCONCELOS, H.L., LAURANCE, W.F., ZIMMERMAN, B., TOCHER, M. \& BORGES, S. 1999. Matrix habitat and species richness in tropical forest remnants. Biol. Conserv. 91:223-229. http://dx.doi.org/10.1016/S00063207(99)00080-4

GOOSEM, M. 2000. Effects of tropical rainforest roads on small mammals: fragmentation, edge effects and traffic disturbance. Wildlife Res. 29(3)277-289. http://dx.doi.org/10.1071/WR01058

INSTITUTO BRASILEIRO DE GEOGRAFIAE ESTATÍSTICA-IBGE. 2004. Brasilian vegetation map. Scale 1:5.000.000. www.ibge.gov.br (último acesso em 20/12/2009)

INSTITUTO NACIONAL DE PESQUISAS ESPACIAIS - INPE. 2006. Monitoring of the Brazilian Amazon forest by satellite: Project PRODES. http://www.obt.inpe.br/prodes/index.html (último acesso em 15/06/2009).

IVANAUSKAS, N.M., MONTEIRO, R. \& RODRIGUES, R.R. 2004. Estrutura de um trecho de floresta Amazônica na bacia do alto rio Xingu. Acta amazon. 34(2):281-305.

JORGENSEN, E.E. 2004. Small mammal use of microhabitat reviewed. J. Mammal. 85: 531-539. http://dx.doi.org/10.1644/BER-019

KAPOS, V. 1989. Effects of isolation on the water status of forest patches in the Brazilian Amazon. J. Trop. Ecol. 5:173-185. http://dx.doi.org/10.1017/ S0266467400003448

KERN, N.G. 1981. The influence of fire on populations of small mammals of the Kruger National Park. Koedoe 24:125-157.

KREFTING, L.W. \& AHLGREN, C. E. 1974. Small mammals and vegetation changes after fire in a mixed conifer-hardwood forest. Ecology 55:1391-1398. http://dx.doi.org/10.2307/1935467

LACHER, T.E. \& ALHO, C.J.R. 2001. Terrestrial Small Mammal richness and habitat associations in an Amazon Forest - Cerrado Contact Zone. Biotropica 33(1):171-181.

LAURANCE, W.F. 1994. Rainforest fragmentation and the structure of small mammal communities in tropical Queensland. Biol. Conserv. 69:23-32. http://dx.doi.org/10.1016/0006-3207(94)90325-5

LAURANCE, W.F. 2008. Theory meets reality: how hatitat fragmentation research has transcended island biogeographic theory. Biol. Conserv. 141:1731-1744. http://dx.doi.org/10.1016/j.biocon.2008.05.011 
LAURANCE, W.F., LOVEJOY, T.E., VASCONCELOS, H.L., BRUNA, E.M., DIDHAM, R.K., STOUFFER, F.C., GASCON, C., BIERRAGAARD, R.O., LANCE, S.G. \& SAMPAIO, E.E. 2002. Ecosystem decay of Amazonian forest fragments: a 22-year investigation. Conserv. Biol. 16(3):605-618. http://dx.doi.org/10.1046/j.1523-1739.2002.01025.x

LAURANCE, W.F. \& VASCONCELOS, H.L. 2009. Conseqüências ecológicas da fragmentação florestal na Amazônia. Oecol. Bras. 13:434 -45. http://dx.doi.org/10.4257/oeco.2009.1303.03

LAURANCE, W.F. \& WILLIAMSON, B. 2001. Positive feedbacks among forest fragmentation, drought, and climate change in the Amazon. Conserv. Biol. 15 (6):1529-1535. http://dx.doi.org/10.1046/j.15231739.2001.01093.x

MALCOLM, J.R. 1997. Biomass and diversity of small mammals in Amazonian forest fragments. p. 207-220. In Tropical Forest Remnants - ecology, management, and conservation of fragmented. (W.F. Laurance \& R.O. Bierregaard, eds.). The University of Chicago Press, Chicago.

MARES, M.A. \& ERNEST, K.A. 1995. Population and community ecology of small mammals in a gallery forest of central Brazil. J. Mammal. 76(3):750-768. http://dx.doi.org/10.2307/1382745

MESQUITA, R., DELAMÔNICA, P. \& LAURANCE, W.F. 1999. Effects of surrounding vegetation on edge-related tree mortality in Amazonian Forest fregments. Biol. Conserv. 91:129-134. http://dx.doi.org/10.1016/ S0006-3207(99)00086-5

MONTEIRO, A.L.S., SOUZA-JUNIOR, C.M., BARRETO, P.G., PANTOJA, F.L.S. \& GERWING, J.J. 2004. Impacts of logging and fire on transitional tropical forest in the southeastern Brazilian Amazon. Sci. For. 665:11-21.

NEPSTAD, D.C., STICKLER, C.M. \& ALMEIDA, O.T. 2006. Globalization of the Amazon soy and beef industries: opportunities for conservation. Conserv. Biol. 20:1595-1603. PMid:17181794. http://dx.doi.org/10.1111/ j.1523-1739.2006.00510.x

NUPP, T.E. \& SWIHART, R.K. 2000. Landscape-level correlates of smallmammal assemblages in forest fragments of farmland. J. Mammal. 81:512-526. http://dx.doi.org/10.1644/1545-1542(2000)081\&lt;0512:L LCOSM\&gt;2.0.CO;2

OJEDA, R.A. 1989. Small-mammal responses to fire in the Monte Desert, Argentina. J. Mammal. 70(2):416-420. http://dx.doi.org/10.2307/1381531

OLIVEIRA, J.A. \& BONVICINO, C.R. 2006. Ordem Rodentia. In Mamíferos do Brasil. (N.R. Reis, A.L. Peracchi, W.A. Pedro \& I.P. Lima, eds.). Editora da Universidade Federal de Londrina, Londrina, 437p., p.347-400.

PARDINI, R. 2004. Effects of forest fragmentation on small mammals in an Atlantic Forest landscape. Biodivers. Conserv. 13:2567-2586. http:// dx.doi.org/10.1023/B:BIOC.0000048452.18878.2d

PASSAMANI, M. 1995. Vertical stratification of small mammals in Atlantic Hill Forest. Mammalia 59(2):276-279.

QUEIROZ, F.A. 2009. Impactos da sojicultura de exportação sobre a biodiversidade do Cerrado. Soc. Nat. 21(2):193-209. http://dx.doi. org/10.1590/S1982-45132009000200013

QUINN, R. 1979. Effects of fire on small mammals in the chaparral. CalNeva Wildfire Transactions Report, California State University, 133p.

RANA, B.D. 1985. Effect of fire on small mammals of a natural grassland community. Mammalia 49:485-489. http://dx.doi.org/10.1515/ mamm.1985.49.4.485
ROSSI, R.V., BIANCONI, G.V. \& PEDRO, W.A. 2006. Ordem Didelphimorphia. In Mamíferos do Brasil (N.R. Reis, A.L. Peracchi, W.A. Pedro \& I.P. Lima, eds.). Editora da Universidade Federal de Londrina, Londrina, 437p., p.27-66.

SANTOS-FILHO, M., SILVA, D.J. \& SANAIOTTI, T.M. 2008. Edge effects and landscape matrix use by a small mammal community in fragments of semideciduous submontane forest in Mato Grosso, Brazil. Braz. J. Biol. 68(4):703-710. http://dx.doi.org/10.1590/S151969842008000400004

SHERBURNE-JUNIOR, F.C. 1959. The Effects of Fire on a Population of Small Rodents. Ecology. 40(1):102-108. http://dx.doi.org/10.2307/1929926

SILVA, J.M.C. \& BATES, J.M. 2002. Biogeographic patterns and conservation in the South American Cerrado: a tropical savanna hotspot. BioScience. 52(3):225-233. http://dx.doi.org/10.1641/00063568(2002)052[0225:BPACIT]2.0.CO;2

SILVA, M.N.F., RYLANDS, A.B. \& PATTON, J.L. 2001. Biogeografia e conservação da mastofauna na floresta amazônica brasileira. In Biodiversidade na Amazônia Brasileira: avaliação e ações prioritárias para a conservação, uso sustentável e repartição de benefícios (J.P.R. Capobianco, V.A. Veríssimo, A. Moreira, D. Sawyer, I. Santos \& L.P. Pinto, orgs). Instituto Socioambiental, São Paulo, 540p., p.110-130.

SIMON, N.P.P., STRATTON, C.B., FORBES, G.J. \& SCHWAB, F.E. 2002. Similarity of small mammal abundance in post-fire and clearcut forests. Forest. Ecol. Manag. 165:163-172. http://dx.doi.org/10.1016/S03781127(01)00613-2

SOARES-FILHO, B.S., NEPSTAD, D.C. \& CURRAN, L.M. 2006. Modelling conservation in the Amazon basin. Nature 440:520-523. PMid:16554817. http://dx.doi.org/10.1038/nature04389

STEVENS, S.M. \& HUSBAND, T.P. 1998. The influence of edge on small mammals: evidence from Brazilian Atlantic forest fragments. Biol. Conserv. 85:1-8. http://dx.doi.org/10.1016/S0006-3207(98)00003-2

TALAMONI, S.A., COUTO, D., CORDEIRO-JUNIOR, D.A. \& DINIZ, F.M. 2008. Diet of some species of Neotropical small mammals. Mamm. Biol. 73:337-341. http://dx.doi.org/10.1016/j.mambio.2007.09.008

TORRE, I. \& DÍAZ, M. 2004. Small mammal abundance in Mediterranean post-fire habitats: a role for predators? Acta Oecol. 25:137-143. http:// dx.doi.org/10.1016/j.actao.2003.10.007

VIEIRA, E.M. 1999. Small mammal communities and fire in the Brazilian Cerrado. J. Zool. 249:75-81. http://dx.doi.org/10.1111/j.1469-7998.1999. tb01061.x

VIEIRA, E.M., IOB, G., BRIANI, D.C. \& PALMA, A.R.T. 2005. Microhabitat selection and daily movements of two rodents (Necromys lasiurus and Oryzomys scotti) in Brazilian Cerrado, as revealed by a spool-andline device. Mamm. Biol. 70(6):359-365. http://dx.doi.org/10.1016/j. mambio.2005.08.002

VIEIRA, E.M. \& MARINHO-FILHO J. 1998. Pre-and Post-Fire habitat utilization by rodents of Cerrado from Central Brazil Biotropica 30(3):491-496. http://dx.doi.org/10.1111/j.1744-7429.1998. tb00086.x

VIEIRA, E.M. \& MONTEIRO-FILHO, E.L. 2003. Vertical stratification of small mammals in the Atlantic rain forest of South-eastern Brazil. J. Trop. Ecol. 19:501-507. http://dx.doi.org/10.1017/S0266467403003559

WILLIAMS-LINERA, G. 1990. Vegetation structure and environmental conditions of forest edges in Panamá. J. Ecol. 78:356-373. http://dx.doi. org/10.2307/2261117 